\title{
Analisis Perbandingan Kualitas Briket Arang Bonggol Jagung dengan Arang Daun Jati
}

\author{
Dwi Sukowati*, Triat Adi Yuwono, Asti Dewi Nurhayati \\ Universitas Nahdlatul Ulama Purwokerto \\ *Email: d.sukowati@unupurwokerto.ac.id
}

DOI: https://doi.org/10.33369/pendipa.3.3.142-145

\begin{abstract}
[Comparative Analysis of the Quality of Corn Charcoal Briquettes with Teak Leaves Charcoal] This study is a preliminary study that aims to determine the quality of briquettes from different biomass raw materials, namely corncobs and teak leaves. Utilization which is still not maximized from corncobs and teak leaves in the biomass energy field made the initial thought of the study. In addition, both of these raw materials have lignocellulosic contents which are likely to be used as biomass raw materials, especially briquettes. The research method used is an experiment with the research procedure is the manufacture of the two briquettes then the products are analyzed and compared. Both of these raw materials receive the same treatment in the manufacturing process. The composition of the adhesive used is $5 \%$ of the main ingredient. The adhesive used is starch. Both briquettes were tested for quality including water content, ash content, volatility, and heating value. The results of testing the water content, ash content, volatile content, the calorific value of corn cobs briquettes and teak leaves charcoal briquettes are, respectively, $3.62 \%$ and $5.39 \%$ water content; ash content of $4.84 \%$ and $3.14 \%$; volatile content of $11.75 \%$ and 25.86\%; The heating value is $5653.99 \mathrm{cal} / \mathrm{g}$ and $7222.95 \mathrm{cal} / \mathrm{g}$. From the results of the analysis, teak leaf charcoal briquettes dominate better quality than corn cobs charcoal briquettes, the water content of teak leaf charcoal briquettes is still higher. When compared with the SNI set value, the two briquettes have met the briquette standards that are suitable to be used as substitutes for alternative fuels.
\end{abstract}

Keywords: Briquette quality; Corn cobs; teak leaves.

(Received August 14, 2019; Accepted October 5, 2019; Published October 22, 2019)

\begin{abstract}
ABSTRAK
Penelitian ini merupakan penelitian pendahuluan yang bertujuan untuk mengetahui kualitas briket dari bahan baku biomassa yang berbeda yaitu bonggol jagung dan daun jati. Pemanfaatan yang masih belum maksimal dari bonggol jagung dan daun jati di bidang energi biomassa menjadikan pemikiran awal penelitian. Selain itu, kedua bahan baku ini mempunyai kandungan ligniselulosa yang berpeluang untuk dijadikan bahan baku biomassa khususnya briket. Metode penelitian yang digunakan adalah eksperimen dengan prosedur penelitiannya adalah pembuatan kedua briket kemudian produknya dianalisis dan dibandingkan. Kedua bahan baku ini mendapat perlakuan sama dalam proses pembuatannya. Komposisi perekat yang digunakan sebesar 5\% dari bahan utama. Perekat yang digunakan adalah tepung kanji. Kedua briket diuji kualitasnya meliputi kadar air, kadar abu, volatile, dan nilai kalor. Adapun hasil pengujian kadar air, kadar abu, kandungan volatile, nilai kalor dari briket arang bonggol jagung dan briket arang daun jati berturut-turut yaitu, kadar air 3,62\% dan 5,39\%; kadar abu 4,84\% dan 3,14\%; kandungan volatile 11,75\% dan 25,86\%; Nilai kalor 5653,99 kal/g dan 7222,95 kal/g. Dari hasil analisis tersebut, briket arang daun jati mendominasi kualitas yang lebih bagus dibanding dengan briket arang bonggol jagung, kelemahannya kadar air briket arang daun jati masih lebih tinggi. Jika dibandingkan dengan nilai yang telah ditetapkan SNI, kedua briket tersebut telah memenuhi standar briket yang layak digunakan sebagai pengganti bahan bakar alternatif.
\end{abstract}

Kata kunci: Kualitas briket; bonggol jagung; daun jati. 


\section{PENDAHULUAN}

Jagung (Zea Mays L.) merupakan tanaman monokotil semusim yang menjadi bahan pangan pokok di Indonesia setelah beras. Tanaman jagung mempunyai banyak manfaat di bidang olahan pangan manusia maupun ternak. Minat akan konsumsi jagung semakin tahun semakin meningkat. Data dari Badan Pangan Statstik, ada tiga lapangan usaha paling dominan dalam mendorong ekonomi Indonesia triwulan I/2018. Tanaman pangan padi dan jagung tumbuh ekspansif 94,08\% yang mengalami panen raya (BPS, 2018). Olahan jagung selain memberikan manfaat juga memberikan pekerjaan rumah khususnya bagi para petani jagung. Keluhan para petani jagung dirasa saat melakukan observasi di dua wilayah yang berbeda, yaitu Desa Banteran, Kabupaten Banyumas dan Desa Mentasan, Kabupaten Cilacap. Keluhannya adalah penumpukan limbah jagung yang masih belum teratasi maksimal. Limbah jagung merupakan limbah organik yang jika diolah dengan maksimal dapat memberikan manfaat banyak dan menambah income perekonomian. Salah satunya adalah energi alternatif briket. Selain limbah jagung, limbah yang belum banyak dilirik adalah daun.

Produk energi alternatif briket dapat memanfaatkan limbah jagung dan daun sebagai komponen utamanya. Kriteria yang harus dimiliki suatu tanaman menjadi bahan bakar energi adalah kandungan selulosa. Semua bahan yang mengandung lignit dan selulosa dapat di densifikasi (Sharma dkk., 2015). Densifikasi adalah proses pengepresan. Selama proses densifikasi, partikel menyusun ulang sendiri pembentukan massa secara keseluruhan di mana sebagian besar partikel tetap sebagian besar mempertahanka sifat asli mereka, meskipun energinya hilang (Frodeson dkk., 2019). Bonggol jagung memiliki kandungan selulosa $42 \%$, hemiselulosa $33 \%$, lignin $18 \%$, abu $1,5 \%$ dan 5,5\% bahan lain (Schwietzke dkk., 2009).

Limbah daun yang digunakan disini adalah daun jati. Jati dikenal dengan kayu primer bernilai ekonomi tinggi. Pohon besar, berbatang lurus, dan berdaun besar yang luruh pada musim kemarau (Thoha dan Fajrin, 2010). Lamid, dkk. (2013), pada penelitiannya yang berjudul Inokulasi Bakteri Selulolitik Actinobacillus sp. Asal Rumen pada Daun Jati Menurunkan Serat
Kasar dan Meningkatkan Protein Kasar mengemukakan bahwa kandungan lignoselulosa pada daun jati tinggi, sehingga menjadi kendala dalam mengolah daun jati sebagai pakan ternak ruminansia. Oleh karena itu, daun jati berpotensi lebih mudah diubah menjadi bahan bakar alternatif briket. Tidak hanya di Indonesia, di Sri Lanka Jati dapat tumbuh degan sangat baik di dataran rendah, sedang, dan tinggi (Satheesan dkk., 2016). Daun jati jika dibakar akan cepat habis, oleh karena itu pembriketan menjadi langkah yang tepat untuk mengkonversi daun jati menjadi produk energi. Pemanfaatan limbah bonggol jagung menjadi briket tentunya akan membawa angin segar khususnya petani jagung. Begitu juga dengan limbah daun jati akan mengurangi penggunaan kayu bakar pada industri yang berkaitan dengan pembakaran.

Berdasarkan metode pembuatannya, briket terbagi menjadi dua jenis yaitu briket bioarang dan biobriket. Briket bioarang dibuat melalui proses pengarangan dari bahan utama sedangkan biobriket tidak melalui proses pengarangan. Briket dengan kualitas yang baik memiliki sifat seperti tekstur yang halus, tidak mudah pecah, keras, penyalaan yang baik, aman bagi manusia dan lingkungan (Jamilatun, 2008). Oleh karena itu, briket yang berkualitas minimal memenuhi standar yang telah ditetapkan (SNI 01-62352000). Komponen yang harus dipenuhi antara lain, nilai kalor $\geq 5000 \mathrm{kal} / \mathrm{g}$, kadar abu yang dihasilkan maksimal 8\%, kadar air maksimal 8\%, volatile yang hilang pada pemanasan $950{ }^{\circ} \mathrm{C}$ maksimal 15\%. Diantara kedua briket yang dihasilkan, briket bioarang memiliki kualitas lebih tinggi dibanding biobriket (Sulistyaningkarti dkk., 2017). Tujuan penelitian ini adalah menganalisis perbandingan kualitas tingkat energi kalor, kadar air, kadar abu, volatile dari briket bonggol jagung dan daun jati. Hasil perbandingan ini digunakan untuk penelitian lanjutan dalam mencari komposisi terbaik bahan baku briket dari bonggol jagung maupun daun jati.

\section{METODE PENELITIAN}

Metode Penelitian yang digunakan adalah metode eksperimen comparative, dengan dua sampel yaitu bonggol jagung dan daun jati, komposisi perekat yang digunakan sebesar $5 \%$. Penelitian ini dilaksanakan di laboratorium 
terpadu Universitas Jenderal Soedirman tanggal 15 Juni 2019.

Pengumpulan data didapat melalui tiga tahap uji sampel dari briket. Adapun prosedur pembuatan briket bioarang dapat terlihat pada gambar berikut.

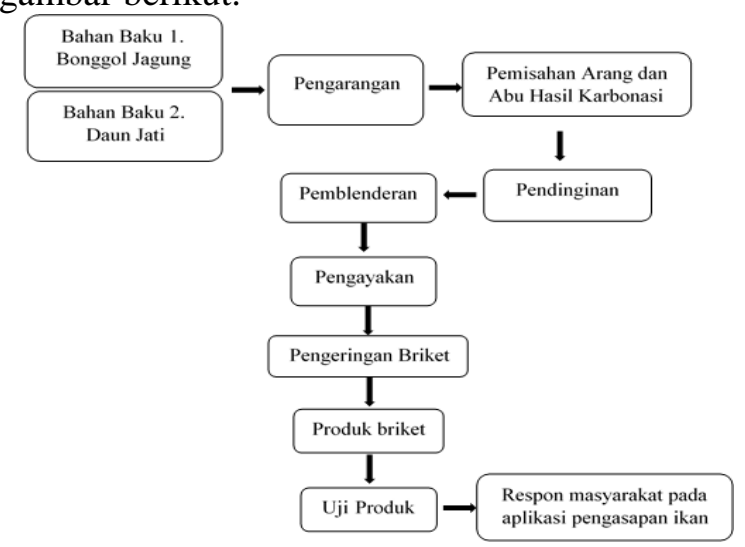

Gambar 1. Prosedur penelitian

\section{HASIL DAN PEMBAHASAN}

Kadar air

Kadar air suatu briket dikatakan baik jika tidak lebih dari $8 \%$. Semakin sedikit kadar air yang dikandung suatu briket maka kualitas briket tersebut semakin bagus. Kandungan kadar air briket dipengaruhi oleh luas permukaan pori-pori arang dan kadar karbon terikat yang terdapat pada briket (Kahariayadi dkk., 2015). Hasil kadar air briket arang bonggol jagung dengan daun jati terlihat pada grafik berikut.

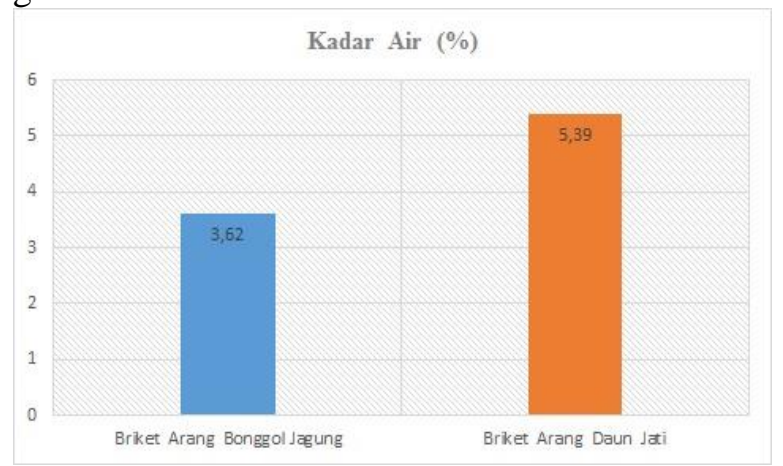

Gambar 2. Grafik Kadar Air Briket Arang

Bonggol Jagung dan Briket Arang Daun Jati

Terlihat pada grafik perbandingan tersebut, persentase kadar air briket arang bonggol jagung lebih rendah. Artinya, kualitas briket berdasar kadar air dimiliki oleh briket arang bonggol jagung. Tetapi jika dilihat dari standar SNI, kedua briket tersebut memenuhi standar karena dibawah $8 \%$.

\section{Kadar $a b u$}

Sesuai standar SNI kadar abu yang harus dimiliki briket tidak lebih dar $8 \%$. Semakin kecil nilai kadar abu, semakin bagus kualitas briket, karena jika kadar abu tinggi mengartikan briket tersebut mengandung silika yang tinggi juga. Unsur silika merupakan unsur yang memiliki pengaruh kurang baik terhadap kualitas briket. Dari hasil penelitian yang didapat Gambar 2., briket arang bonggol jagung memiliki kadar abu lebih tinggi yaitu 4,84\%. Artinya kualitas briket dari segi kadar abu dimiliki oleh briket arang daun jati dengan kandungan silika lebih rendah dibanding bonggol jagung.

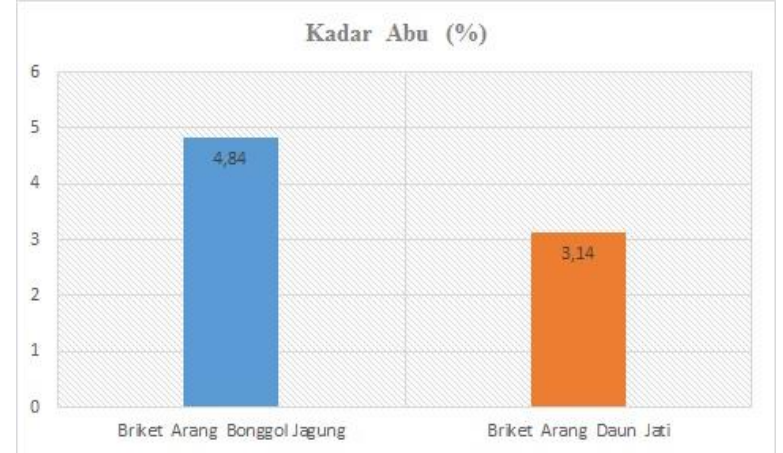

Gambar 3. Grafik Kadar Abu Briket Arang Bonggol Jagung dan Briket Arang Daun Jati

\section{Volatile}

Kadar volatile dalam briket menunjukkan bahwa saat proses pembakaran dapat dilihat seberapa banyak kadar karbon yang terikat. Kadar karbon bernilai tinggi jika kadar abu, kadar air dan kadar zat menguap briket rendah (Putri dkk., 2017). Semakin tinggi kadar karbon pada briket, semakin baik kualitas briket tersebut. Tinggi rendahnya kadar zat menguap/volatile matter pada briket di pengaruhi juga oleh waktu dan suhu pada proses pengarangan. Semakin besar suhu dan waktu pengarangan maka semakin banyak zat menguap terbuang sehingga pada saat pengujian kadar zat menguap akan diperoleh kadar zat menguap yang rendah (Yuliah dkk., 2017). Dari hasil pengamatan, nilai volatile briket arang daun jati lebih tinggi dibanding briket arang bonggol jagung yaitu $25,86 \%$. Artinya, hasil penelitian ini 
sesuai karena semakin rendah kadar abu semakin tinggi kadar volatilenya.

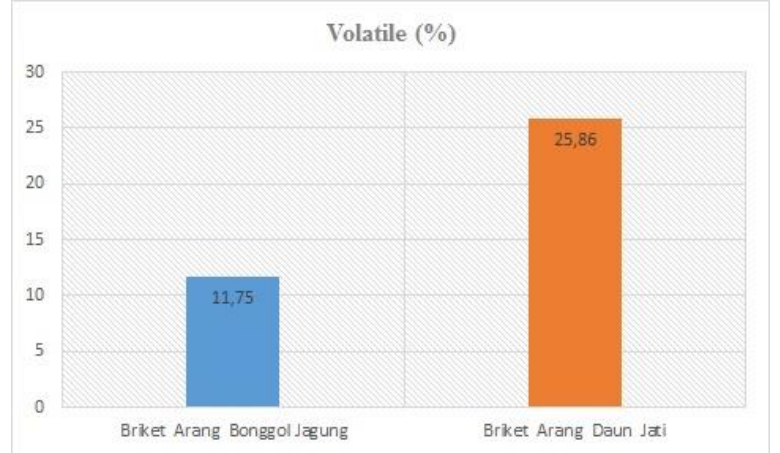

Gambar 4. Grafik Kadar Volatile Briket Arang Bonggol Jagung dan Briket Arang Daun Jati

\section{Kalor}

Nilai kalor merupakan komponen terpenting dalam menentukan kualitas briket. Jika nilai kalor suatu briket rendah dan tidak memenuhi standar SNI maka dapat dikatakan briket tidak layak untuk digunakan sebagai energi alternatif. Dari hasil penelitian didapatkan seperti pada Gambar 5. Nilai kalor briket arang daun jati lebih tinggi dibanding dengan nilai kalor briket araqng bonggol jagung sebesar $7222,95 \mathrm{kal} / \mathrm{g}$. Nilai kalor briket arang daun jati telah memenuhi standar SNI. Artinya, briket arang daun jati dapat menjadi salah satu alternatif pengganti bahan bakar khususnya kayu.

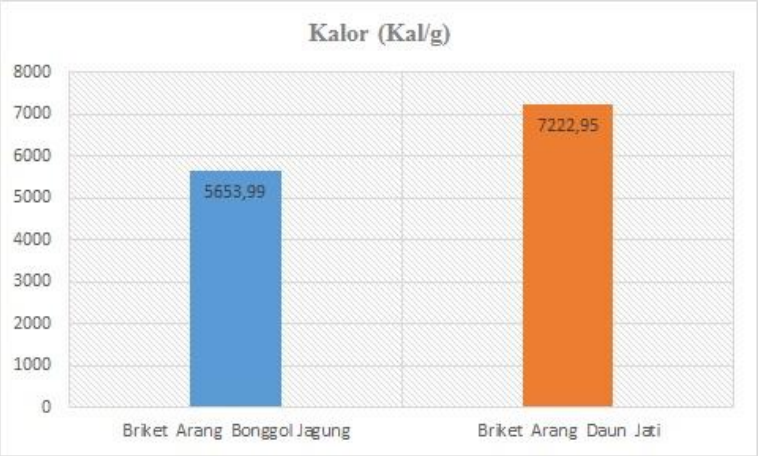

Gambar 5. Grafik Nilai Kalor Briket Arang Bonggol Jagung dan Briket Arang Daun Jati

\section{KESIMPULAN}

Dari hasil analisis, briket arang daun jati mendominasi kualitas yang lebih bagus dibanding dengan briket arang bonggol jagung, kelemahannya kadar air briket arang daun jati masih lebih tinggi. Jika dibandingkan dengan nilai yang telah ditetapkan SNI, kedua briket tersebut telah memenuhi standar briket yang layak digunakan sebagai pengganti bahan bakar alternatif.

\section{UCAPAN TERIMA KASIH}

Puji syukur kehadirat Allah SWT yang telah memberikan segala nikmat dan karunia-Nya hingga penelitian ini selesai. Terima kasih kepada Universitas Nahdlatul Ulama Purwokerto khususnya Fakultas Sains dan Teknologi yang telah memberikan dukungan atas jalannya penelitian ini.

\section{DAFTAR PUSTAKA}

Frodeson, S., Henriksson, G., Berghel, J. (2019) Effects of moisture content during densification of biomass pellets, focusing on polysaccharide substances, Elsevier: Biomass and Bioenergy, 122, 322-330.

Jamilatun, S. (2008) Sifat-sifat Penyalaan dan Pembakaran Briket Biomassa, Briket Batubara dan Arang Kayu, Rekayasa Proses, 2(2), 37-40.

Kahariayadi, A., Setyawati, D., Nurhaida, Diba, F., Roslinda, E. (2015) Kualitas Arang Briket Berdasarkan Persentase Arang Batang Kelapa Sawit (Elaeis Guineensis Jacq) Dan Arang Kayu Laban (Vitex Pubescens Vahl), Hutan Lestari, 3(4), 561568.

Lamid, M., Julita, A.F.E., Widjaya, Ng.M.R. (2013) Inokulasi Bakteri Selulolitik Actinobacillus sp. Asal Rumen pada Daun Jati Menurunkan Serat Kasar dan Meningkatkan Protein Kasar, Jurnal Veteriner, 14 (3), 279-284.

Putri, R.E., Andasuryani (2017) Studi Mutu Briket Arang Dengan Bahan Baku Limbah Biomassa, Jurnal Teknologi Pertanian Andalas, 21(2).

Satheesan, T., Sivanathawerl, T., Sivachndran, S., Phuspakumara, D.K.N.G. (2016) Distribution, Growth and Aboveground Biomass of Teak (Tectona grandis L.) Plantation in Mullaitivu District of Sri Lanka, International Journal of Scientific and Research Publications, 6 (3), 72-76.

Schwietzke, S., Kim, Y., Ximenes, E., Mosier, N., and Ladisch, M. (2009) Ethanol Production from Maize., 
Biotechnology in Agriculture and Forestry, 63,. 347-364.

Sharma, M.K., Priyank, G., Sharma, N. (2015) Biomass Briquette Production: A Propagation of Non-Convention Technology and Future of Pollution Free Thermal Energy Sources, American Journal Engineering Reseach, 04 (02), 4450.

Sulistyaningkarti, L., Budi U. (2017) Pembuatan Briket Arang dari Limbah Organik Tongkol Jagung Dengan Menggunakan Variasi Jenis dan Persentase Perekat. Kimia dan Pendidikan Kimia. 2 (1), 45-53.

Thoha, M.Y. dan Fajrin, D. E. (2010) Pembuatan briket arang dari daun jati dengan sagu sebagai pengikat, Teknik Kimia, 17(1), 3443.

Yuliah, Y., Suryaningsih, S., Ulfi K. (2017) Penentuan Kadar Air Hilang Dan Volatile Matter Pada Bio-Briket Dari Campuran Arang Sekam Padi Dan Batok Kelapa, 01(01), 51-57. 